\title{
On the Cultivation of College Students' Autonomous English Learning Ability In the Age of Big Data
}

\author{
LI Zhaoying \\ Jilin Business and Technology College, Changchun 130000,China \\ lizhaoying@126.com
}

Keywords: Big data age; College students; Learning mode

\begin{abstract}
The coming of the big data age has a revolutionary impact on the development of society, which has promoted changes in thinking, business and management. In the same way education is also greatly affected. Universities are the cradle of creative talents. Under the impact of big data, the traditional university learning model is challenged and is needed badlyto change. The author holds the opinion that in the future the learning pattern of college students will be changed from passive to autonomous. The transition to lifelong learning depends on the synergy of students, teachers and schools. In the big data era, how to make good use of data platform to stimulate the enthusiasm of students' English learning and improve their autonomous learning English ability is a problem which should be solved currently in the research of college English teaching. Autonomous learning is the main form of college students' learning, and it is a necessary condition for the comprehensive development of college students.This paper introduces the current situation of college students' autonomous learning, discusses the necessity of college students' English autonomous learning, and puts forward several methods of training college English autonomous learning ability.
\end{abstract}

\section{Introduction}

The concept of autonomic learning has caused wide attention in the field of foreign language teaching. After that a large number of scientific reseaerch were carried out around it, including its discussion of its definition, theoretical basis and application strategy. In China educators began to explore English autonomous learning in the 1980s and with the accumulation of the theory and practical experience people have realized that the traditional "preaching, knowledge and to reassure" type cannot meet the requirements of time requirement, especially in the information age which raises higher expectation and demands on the quality of higher education talents . In today's English teaching students - centered class has gained more and more acceptance . And the research on autonomic learning has gained wide attwention. Therefore, changing the traditional teaching mode and cultivating students' autonomic learning has become the key of college English teaching reform. In the big data age ,with the rapid development of information technology and the wide spread of internet, college students have owned wider platform for autonomic learning .How to take advantage of information technology and supply more energy to students' learning and at the same

McKinsey is the earliest to put forward era of "big data" which is a well-known consulting firm in the world. As Mr. McKinsey said, the data has penetrated into every industrytime make English study and practical application. Are some serious questions which we should consider today and the business functional areas and has become an important production factors. "Big data" has emerged in the field of physics, biology, environment as well as ecology, military, finance, telecommunications and other industries for a long time. The big data "has become a hot topic at home and abroad in each media, then what kind of impact will big data bring us?

\section{The opportunities the big data age bring to college students}

Quick and easy. The age of big data brings a big opportunity for college students to learn.

First, the big data age is quick and easy. Big data era has the characteristic of rapidness and people's learning is no longer restricted by time and place and students can learn everywhere at any 
time, and they can walk in the forefront of The Times and underatand the latest knowledge and information in the first time. In the past knowledge was mainly learned through books, which tended to be limited by time lag and affected learning effects and knowledge updates.

Economical and efficient. The family background of college students is different, and college students come from different family background. Students with poor family environment can't afford to pay for after-school training. In the age of big data, many open courses are free, and students can find learning materials so long as there is time and need for learning, so the economy is no longer a constraint affect students' learning. In addition, big data also promotes students' more effective learning . Students can master their own learning process, so that they are able to learn more effectively and targeted.

Resource sharing. The big data age has the characteristics of rich learning resources which will be presented to the students. Online learning brings the distance between international, regional and intercollegiate and all learners have equal rights in learning resource utilization. In the near future, due to the popularity of online education, everyone can be on the school, which will no longer be a dream and the problem of education resources shortage will also get some relief. The significance of education online is not just education. The increase of opportunity is the change of learning style. In traditional schools, we are to accept education, but in the network school, everyone can get learning materials at any time anywhere.

Free choice. The free choice means that students can truly become masters of learning, all learning behaviors are the process and result of the learner's is their own choice. Students can choose the content, the time, the way, the companion,depending on their own interests and needs. In traditional learning patterns, teachers are the source of knowledge, students can only "be chosen", books are the teaching materials, the teacher is the direction of the direction.

\section{The ways to Cultivate college students' autonomous learning ability}

The measures to cultivate college students' autonomy in English in the information age Entering the age of information, the need for English learning is becoming more and more urgent and with the help of information technology and network resources, studying independently is becoming more and more convenient . The following provides some measures to promote the development of university students' autonomous learning ability in the information age.

Cultivate the awareness of self-learning. Cultivating the awareness of self-learning is a good way to cultivate the ability of college atudents' autonomous learning. As we all know, students are the main characters of English learning. However, nowadays a large number of students study for the test and after graduation employment. In this case, students do not usually study hard and we can find the phenomenon of temporary cramming, which undermines the effectiveness of learning. Therefore, teachers should help students to understand their academic concepts correctly,making them knowthat it is the main method of learning in the university. For newly enrolled college freshmen, they should be guided by the education and the professional learning method, and cultivate their own independent learning consciousness.

Stimulate students'interest of independent learning in English. Interest is the best teacher in the learning, Ifstudents have no interest in learning English, the learning motivation will diminish.

Learning is hard to keep, so stimulating students' interest in English is one of the necessary conditions for cultivating their self-learning ability. Stimulating students' interest in learning English is connected with teachers' positive guidance and their teaching art. Apart from some traditional method of teaching,teachers can also apply modern multimedia technology and the Internet to improve students' interest in English learning.

Create a learning environment . We should help students to create a learning environment conducive to learning English. English is a language and we cannot leave the environment to study a language. It is an effective way of learning English to make learners immerse in the environment of using the language and make meaningful communication. Entering the information age, multimedia technology has universal in colleges and universities. The teacher can increase the students' language 
input in class through music, video and so on ; They can also encourage students to make friends with foreigners on the Internet or on campus in their spare time and learn language in a relaxed, real and natural language environment.

The use of language in real environment can effectively enhance the students' learning achievement, so that the learning desire will continue to promote the learners' independent learning outside the English classroom.

Study in groups. It is a good idea to study in groups, to publish the subject of the course, to encourage students to find the materials through the Internet, and to make the courseware and report the course. With the support of information technology, these formerly troubled things became very convenient. Through such activities, let the students truly become the center of the class and at the same time make them make full use of their strengths and to find the most suitable learning style for their own , make greatly the development of autonomous learning ability.

Build information evaluation system. Build the information evaluation system and promote the independent learning by the diversity evaluation. The diversity evaluation is an effective measure of promoting independent learning by encouraging students to study and practicing their reflective ability. In traditional teaching, the teacher is the only one who evaluates the subject. The teacher's evaluation of the students is mainly the performance of the classroom and the final exam scores, which are influenced by many factors and difficult to be objective. Unfair and unobjective evaluation often discourages students' motivation to study, and it is difficult to promote the students' interest in self-study ability. With the aid of information technology, can establish an evaluationsystem, realize the teacher to the student, student to student, student to teacher multi-angle evaluation, such as multivariate evaluation goals are met.

\section{Conclusion}

For a long period of time, because of the old concpt of education and the limitatioon of learning hardware and software, college students' autonomous English learning is not high, which affects the improvement of college English teaching quality.

Entering the information age, the demand of talents and the level of demand has entered a new level, the reform of college English teaching and cultivating students' autonomous learning ability become imminent. The rapid development of information technology and the explosive growth of network resources have injected the vitality of times into the cultivation of students' self-learning ability

We should take effective measures to improve the independent learning consciousness and ability of college students.

Specific measures is the precondition of the student-centered, build favorable autonomous learning environment, make students groups for group learning, find learning materials after class to make courseware and expand the class boundary, etc.

In the era of big data, students can choose learning content and learning style, and through the Internet from anywhere in the world of online learning help, get feedback from teachers and students about their learning situation.

In my opinion, the independent study here is not the study alone, but the independent study, the full study. A person's vision is narrow, one-sided, and needs to be integrated in the field of vision in the process of communication.

\section{References}

[1] The Influence of Books on Students' Autonomous Learning Ability in English Teaching[J]. Zhangdi. Education Outside China. 2017(08)

[2] Using Independent Evaluation to Promote Students' Independent Learning[J]. Majing. Journal of Heze University. 2017(01) 
[3] The Study of the Independent Learning Ability of College Students in English [J]. Huang tingting, Shaanxi, Education (High Education).

[4] On How College Students Autonomously Learn English In the Internet Age - A Review of Autonomou Studies of College Englishs in Network Era [J]. Journal of Cyanine News Lovers. 2016 (12).

[5] How to Improve the Independent Learning Ability of University Students [J]. Song Xuanning. Literature Education (lower).2016 (01).

[6] On the Cultivation of Students' Self-learning Ability [J]. Liang Dongmei,

Li bao. Mass Technology. 2011 (2005)

[7] Talk About Self-study [J]. Li Yunxiang, Cai Wei, Miao Zhixiu. Legal Exposition (Middle 10). 2014 (2004)

[8] The Transformation of the Role of a Teacher in Self-learning [J]. Zuolin, Zhu lei. Science and technology. 2011 (2009) 